\title{
Social Impediments of the Third World Women: A Study of Manju Kapur's A Married Woman (2002)
}

\author{
Rifat Binte Joynal, Maruf Rahman* \\ Department of English, Noakhali Science \& Technology University, Noakhali, Bangladesh \\ Email: rifatbintenstu@gmail.com, ${ }^{*}$ rahmanmaruf2548@gmail.com
}

How to cite this paper: Joynal, R. B., \& Rahman, M. (2020). Social Impediments of the Third World Women: A Study of Manju Kapur's A Married Woman (2002). Advances in Literary Study, 8, 167-177. https://doi.org/10.4236/als.2020.84014

Received: August 11, 2020

Accepted: September 7, 2020

Published: September 10, 2020

Copyright $\odot 2020$ by author(s) and Scientific Research Publishing Inc. This work is licensed under the Creative Commons Attribution International License (CC BY 4.0).

http://creativecommons.org/licenses/by/4.0/

\section{(c) (i) Open Access}

\begin{abstract}
The article will detect the social hurdles experienced by the Third World Indian Women in the light of Manju Kapur's celebrated novel, A Married Woman (2002). The obstacles such as early marriage, forced marriage, gender discrimination, domestic work, family tradition, social taboos, education inequality, discourage for degree, patriarchal hegemony, sexual politics that block the way of female freedom, education, employment and empowerment will be explored here. The common picture in the South Asian Indian patriarchy is that either educated or employed all Third World women face some common obstacles. So far been employed or empowered they have to compromise their will and choice for the sake of family or society. Patriarchy means men-women disparity but Indian women are colonized by both religious patriarchy and social taboos. Women in Third World context are restricted by both familial and social obligations. Hence, patriarchy in India is religious patriarchy and social cultures are different for men and women. In this fiction, Kapur's resistant heroines Astha and Pipeelika are intellectually liberated from the tie of patriarchy but again enticed by a lot of social and familial customs they suffer from identity crisis and existential problems.
\end{abstract}

\section{Keywords}

Indian Patriarchy, Social Impediments, Third World Women, Third World Feminism

\section{Introduction}

The present paper is going to find out the social and familial obligations that marginalize the Third World Indian women ages after ages. These obstacles are 
child marriage, forged marriage, housework, domestic violence, gender disparity, discourage for education and degree, social taboos, family prejudice, religious patriarchy, sexual abuse and more. The obstacles interfere the Third World Women's basic rights or human rights such as standard of living, academic education, reproductive health, marriage decision, child birth or abortion and slow or block their progress in typical social structure. Such social barriers are created by the cultures or taboos of a group or community in a traditional framework. A Married Woman (2002) is the second novel by Manju Kapur, Third World feminist writer. The story deals with the story of an educated, employed, upper middle class Delhi woman.

The novel tells the story of Astha, the protagonist and a talented painter who comes of a Delhi-artistic, culture-minded family. She is her parent's only child. Her liberal progressive father wants to educate her, but problem creates her traditionalist mother who just wants to see her daughter settled in a safe arranged marriage. As a girl, Astha is brought up with large supplements of family teachings about her actual duty that is "to be married".

A Married Woman (2002) centers round the life story of Astha from her adolescence to adulthood. The novel narrates her before marital and after marital love affairs. Like a romantic girl, she has her dreams and aspirations. As a common school going girl, she often imagines of handsome and romantic young lover. In her teenage period, she falls in love with a boy of her age, Bunty. They exchanged a number of love letters. It was her first love. But this love affair is interfered by her mother as she complained to Bunty's father that his boy disturbs her daughter. Ultimately, there is the break up between Astha and Bunty.

Leaving behind all the memories with Bunty, she takes entry into a college. During her college days, she again falls in love with Rohan, a teacher of the college. She is emotionally engaged with Rohan. But this relationship is finished within a few days. Rohan refuses to marry her after passing time with Astha.

Finally, she decides to be settled in an arranged marriage and accepts one of her mother's approved suitors. Her marriage is settled with Hemant who is America returned, educated and solvent. Hemant is the only son of his parents, except that he has two married sisters Seema and Sangeeta. Astha's mother thought that it is a nuclear family like them. Besides, Hemant is a nice boy holding a position in society and self-governing business and property.

The wedding ceremony held after Astha's MA exams. In her in-law's house, Astha submerged herself in the role of daughter-in-law and wife. Her husband trains her to follow marital routine. Something like love develops between them, but gradually it starts to reflect a power structure where one is dominative and another is dominated.

They became the parents of a daughter. But like a traditionalist husband, Hemant wants a baby boy. Astha conceives again and gives borth to a son, Himanashu. Astha is honoured with heavy jewellery and all the family members think that the family is complete now. After Himanshu's birth Hemant changes from 
an American father to an Indian father. Taking care of child goes to Astha and she is their both father and mother. In contrary, Hemant is busy with his business.

Astha's love for painting and composing poems are always encouraged by Hemant. As life advances she becomes involved with Theatre Troupe run by Aijaz, a local political activist. All things run smooth. But problems appear when Hemant observes that his wife works for social movements in collaboration with a man. Hemant is liberal regarding Astha's teaching profession and her art works. But he does not like his wife's outside activities. Like a traditionalist husband, Hemant is not happy with her social and political awareness with Aijaz Akhtar Khan. Hemant wants that his wife will perform family duty, teaching career and gallery work and beyond these she has no works.

Next, their married life is disturbed by Hemant's careless view about her good potentials. She has been claimed by her husband for mismanagement, wastefulness, inefficiency and incapability about her family duty. Like an Indian woman she does not want to turn her face from the familial responsibilities of a wife, daughter in law and a mother but she wants to participate in all the decisions of the family. She cannot find the same care, attention and affection from her husband as before. Drawing and painting are the source of relief for her. By writing poems and drawing sketches, she expresses her pain, suffering, anguish.

Next, Astha comes to know about Pipeelika Trivedi, a Hindu girl who marriages this Muslim Theatre activist Aijaz Akhtar Khan out of love by breaking traditions. But Pipeelika becomes a widow after some days of her marriage. Aijaz died by a communal riot. He has left behind a young widow. Now Pippelika Khan is a NGO worker and works for social welfare.

Hemant according to his style accuses Astha on the ground that she spends much time in art and painting than her family duty. Astha says that she wants something of her own. Astha suffers from a serious headache nowadays. Besides her gallery work, she takes care of her kids' homework, kitchen work with her restless mind. This time Astha sells two paintings and earns thirty thousand rupees. Hemant is happy now. Hemant proposes that they have passed fifteen years married life. So on the occasion of their present anniversary, they should go for a holiday. They decided to go for Goa. This tour is arranged from Astha's money that she earns from painting.

As the days are passing, the anniversary of The Street Theatre Group comes. Astha is busy with her secular activities. Astha's mother-in-law is complaining now that she neglects her household duties. She spent two days and three nights for Ayodhaya Andolon. During this time Hemant goes for Delhi for the purpose of business. As she comes from Ayodhaya, she discovers an unexpected thing from her husband's suitcase that is a condom. Astha suspects that her husband is in now another relationship. Their marital relationship now turns to a small boat sinking on the faithless ocean bit by bit.

During her social activities Astha meets with Pipeelika for the first time. Astha seeks for a real company who will touch her soul not her body. Astha falls in love 
with Pipeelika and develops a lesbian relationship. Pipeelika from her part, is a young widow and an outsider from society. Her mother wants to marry her again but she refuses for her bitter experiences for marrying a Muslim who had a relation with Reshana Singh, a classical singer in Street Theatre Group. Both Astha and Pipee have hatred for males and thus they are engaged in a same sex relationship.

One day Astha discovers Hemant's extra-marital relation but he ignores. She discovers that her relationship with Hemant is just a sexual slavery. At last, Astha finds comfort in Pipeelika's arms. She wants to teach her husband and makes a sweet protest by building a lesbian relationship. In the meantime, Pipee goes to US for a Ph. D. degree. Pipee urges Astha to mail her. Her departure from Astha's life was too painful. Finally, Astha comes back to her marital relationship with a heavy heart.

\section{Discussion}

In Indian patriarchy, marriages are imposed on girls. The girls are not allowed to make love or marry a man of their choice. Family is more important to women than to men. The institution of marriage offers to both the agent protection and social acceptability and so majority of women respect this institution. Marriage is her ultimate destiny which implies subordination to man. Females are the objects of family reputation and marriage is a more concerned issue than female education. To quote Kapur: "Astha was brought up properly, as befits a woman, with large supplements of fear." (Kapur: 01) Marriage is the medium of female exploitation in Indian patriarchy. Traditionally, it is taken for granted that a girl's duty is to get married, look after her husband, produce children for the sake of her family and take care of them; while all the creative works should be done by man. It is totally inhuman from the part of society to deprive a girl of her inborn right to survive and fulfill her needs. As Simon de Beauvoir says: "One is not born, but rather becomes, a woman. No biological, psychological, or economic fate determines the figure that the human female presents in society; it is civilization as a whole that produces this creature, intermediate between male and eunuch, which is described as feminine. Only the intervention of someone else can establish an individual as an 'other."' (Beauvoir, 1949)

The exploitation of women in the name of religion and social prestige is going to be reported by the present paper. Like, Anita Desai's Fire on the Mountain (2001), Manju Kapur's A Married Woman (2002) makes a sweet protest against the social norms and customs through the sufferings and suffocations of the Indian Post-colonial women. Manju Kapur is in the notion that by depriving womanhood, the whole humanity is depriving itself as it is constituted of both male and female who are the two wheels of the same chariot and for the defect of the one other lags behind. The Indian patriarchal society is the storeroom of numerous obstacles that are designed for women. In A Married Woman (2002), social injustice against each and every woman is a common scene which is "na- 
turalized" with the idea of "fatalism", meaning that females are fated to do so or to suffer or bear. The social barricades in A Married Woman (2002) will be explored here.

In Third world family, household duties and responsibilities are handled on the shoulder of a woman. She has no escape from household chores even if she is an educated-employed wife. From marital bed to kitchen room she has to tackle all things: obeying husband, cleaning, cooking, washing, ironing, educating children, caring in-laws. Household works are only done by housewives and in these works, their husbands have no participation. In this story, Astha's condition falls in such category. She is both "father and mother" for her children. Fulfilling everybody's needs, nothing is left for her. It is the common picture of a Third World wife. In contrast, in First World countries, household work is a choice determining who cooks or who cleans by the married couples. When a wife in First World countries, clocks long hours in the workplace, her husband pitches in more around the house. But in Indian society, women are not privileged like that of Western women.

In Indian patriarchy, the notion of protection entices women to be sexually passive and humble. Third World women are brought up with the importance of being protected by males. A woman should be protected in her childhood by her father, in her youth by her husband and in her aged days her son should protect her and in this way the woman does not deserve to be free. Such dominant patriarchal rules marginalize women to carry on their individual rights and freedom. As Karthika comments: "Women are treated as the "other" who has got comparatively less power in the society. The muscle power and the equations of strength are used cunningly to make the women believe that they are subordinate human beings." (Karthika, 2015) In this story, almost all the female characters are financially dependent on their fathers, husbands, brothers and sons. Sita, Mrs. Trivedi were dependent on their husbands; Astha's mother-in-law is dependent on her son; Sangeeta for her marital problems decides to live with Astha and therefore, she is dependent on her brother, Hemant. Astha before her marriage was protected by her father. After marriage, she is seen as an employed woman but she is controlled in every case by Hemant. She earns but her money spending is always decided by Hemant.

Motherhood is an obstacle for Third World women. The Third World women often show sense of power and resistance that differs from the First World women. The Third World women often denounce male supremacy by rejecting household chores. But their maternity entices them. A Third World mother can resist patriarchal authority but not her children. Like Radha in Purabi Basu's, short story "Radha Will Not Cook Today", Astha wants to resist male dominance. Radha, in this story, can denounce her husband, mother-in-law by keeping herself from one day's cooking but when her only one son Sadhan says that he is hungry she is in a dilemma what to do (Basu, 2007). Astha in this story builds up a same sex relationship with Pipee in order to be herself and to resist Hemant. 
But when she was with Pipee, she was used to be worried about her children.

In Third World Patriarchal society, gender discrimination starts from the womb and lasts till the tomb. Indian culture is a culture that idolizes sons and dreads the birth of a daughter. So the daughters are not brought up with same perspective like the boys. But in First World, there is no discrimination between son and daughter or there is no custom of son preference. But women in India live and struggle under the oppressive mechanism of a closed society that is reflected in this story. Astha in this story is much traumatized at the uninterested response of members of the family and society at her daughter, Anuradha's birthday. But she obtains an appraisal and sanction of motherhood after the birth of her son-Himanshu. She abhors such a false notion and discrimination between a daughter and a son, such an outlook of Indian traditional society is injurious to equal status of women who "feel caught up in the web of daily life." (Kapur: 76) When Astha gives birth to a boy child, everybody is very happy. Her mother thinks: "When Astha's son was finally born she felt a gratitude as profound as it was shamed. The family is complete at last' said Astha's mother agreed, too happy in the own contribution. Hemant's mother agreed, too happy in the birth of her grandson, carrier of the line, the seed, the name, to respond with her reserve to someone she increasingly felt was her social inferior." (Manju Kapur: 68) Women under the patriarchal pressure and control are subjected to too much more social injustice. They are more discriminated and are biased in lieu of their sex.

In Third World India, women are the victims of religious patriarchy. Indian women are colonized by the power of religion. Virginia Saldanha comments: "Men have been dominant as recipients, interpreters and transmitters of divine messages, while women have largely remained passive receivers of teachings and ardent practitioners' religious rituals. Attitudes developed around patriarchal interpretations of religious belief have defined and shaped the social and cultural contexts of Indian women resulting in their disempowerment and second class status.” (Saldanha, 2016) In Western societies, patriarchy does not subjugate women in league with religion. Western family is patriarchal in nature but patriarchy is not absolute there. But women in India are manipulated by religion and patriarchy uses it as a tool. Indian woman's history of suffering and rebellion against patriarchal dominance remains almost the same. There are old models and newer ones but the paramount question of adjustment or rebellion in search of identity still remains.

Male domination in India leads to woman's subjugation, discrimination, and exploitation presents sexism in its worst form. Karthika says: "Ancient or modern, the society is always male-oriented and views women as objects for pleasure." (Karthika, 2015) More than half of the population of the world is made of woman but she is not treated on par with man despite innumerable evolutions and revolutions. She has the same mental and moral power, yet she is expected to serve, sacrifice, and submit each ill against her peacefully. Her individual self 
has very little recognition in the patriarchal society and so self-effacement is her normal way of life. In Indian society, the institution of marriage holds a place of prominence and the women usually abide by it. Since ancient time in India marriage has been regarded not only as a necessity, but also as a social and religious duty. This religious patriarchy is subjugating women in India.

Women in India are universally subjugated through ancient scriptures and Puranic texts. As Karthika V.K. says: "The story of subjugation of women had its roots in the myths and legends which are popular in India." (Karthika, 2015) The stereotypical myth depicts archetypes of Indian womanhood, such as Sati, Sita, Savitri, Gandhari, Behula showing women in suffering, self-sacrificing roles, and reinforcing conventional myths in a patriotic manner. Society creates such prejudices and stereotypical images for women and those who conform to them are considered as pious and pativrata. Women in Indian society are expected to be passive or submissive. Third World Grandmothers are successfully accomplishing the task of in calculating the woman like qualities in the girls through their stories. These myths are used to train them as faithful wives in order to celebrate the purity and chastity of mythological models. Mythologies, Upanishads, Puranas in India validate the subjugation of women in patriarchal culture.

The dominance of fanatic attitudes, the complexity of caste, class and religious identities in India subjugate women to stereotypical roles. In Third World India, marriage occurs in the same castes or cultures such as Muslim-Muslin, Hindu-Hindu, Shikh-Shikh, and tribe-tribe. Otherwise, it is not acceptable if it happens between different classes or castes. In this story, the marriage between Hindu Pipeelika Trivedi and Muslim Aijaz Khan is not acceptable to the eye of society as they belong to different religions. European ideology motivates them to possess secular ideas. But in Third World society, non-inter-religious, non-inter-cultural marriages are not acceptable. That is why; Hindu-Muslim marriages are hated in Indian terrain. To the eye of society, such marriages are not complete, pure or honourable. Such secularist wives like Pipee are marginalized by the prejudiced fundamentalist ideas.

The Third World women cannot raise voice regarding important issues like their rights to their body, number of pregnancies, decision of conceiving babies, abortion etc. Everything is decided by their husbands. In Third World Social System, a wife is always forced to follow the instructions of husband while the husband does not care for the feelings of wife. Female body becomes the site of forced colonization which the male master uses and abuses according to his own sweet. In Third World context, a wife has to submit willingly or unwillingly, to the demands of husband's body just because she is his wife. The following conversation in this story echoes the marital tragedy of a Third World wife through the character of Astha: "Why? I'm your husband. So what? So everything. You think marriage is just sex." (Kapur: 275) Such marital prerequisites of Third World wives colonize their body, sense and sex. The Indian women are still facing the trauma of exploitation and sexual abuse. It is very common in Indian 
age-old patriarchy which is re-colonizing female body.

Internalized notion that is passed woman after woman is another important obstacle in Third World families. It is the woman herself, who often ill-treats the woman in Indian traditional families. The old women in Third World Indian society are the guardians of patriarchy. They are the followers of the age-old beliefs because they have been already internalized by the thought of patriarchal values. The mother-daughter; mother-in-law-daughter-in-law; and sister-in-lawdaughter-in-law relationships lead to the continuous dilemmas.

In this story, mothers want their daughters to like them but daughters want to learn from their own experiences. In this story, Sita-Astha relationship echoes such truths. Sita tries to arrange her daughter's marriage when she was only sixteenth years old. When Astha is in second year, Sita starts arguing with her husband why he is so indifferent regarding this serious matter. On the other hand, Trivedi-Pipee relationship refreshes previous Sita-Astha relationship. Mrs. Trivedi is intolerant of her daughter's unmarried status and her secular decision and from her parts; she tries her best to convince Pippe not to marry Aijaz. The relationship between Astha and her mother-in-law is based on some stereotyped envies by Astha and domineering attitudes by her mother-in-law. For instances, Astha envies Hemant's close bonds with his parents, his care and financial supports for them. In contrast, she misses her mother. On the other hand, Astha's mother-in-law, out of jealousy, says: "Such a husband" when Astha is gifted "a diamond ring" by Hemant on the occasion of their anniversary. Astha's mother in law thinks that her son is the best son in this world and being the wife of such husband Astha is really lucky. Similarly, Astha-Sangeeta relationship is not friendly one. Sangeta envies Astha's happiness; like Hemant's love and care for her, or her parent's liberal attitudes towards her which she does not find from her husband and in-laws. Due to internalized notions of patriarchy women envy women.

In Indian society, marriage taboo causes obstacles in the path of independent wish and freedom. From her childhood, an Indian girl is taught that she is born to marry, procreate and serve other mutely. She is brought up with the idea that is "Woman is Earth" that is why she has to be docile, humble and loyal as she is going to leave her parental house in order to serve her in-laws' house. In this story, Astha's mother is the guardian of patriarchal values who teaches her to pray to God for a "good husband". To quote Kapur, "Every day in her temple corner in the kitchen, she prayed for a good husband for her daughter." (Kapur: 01) Similarly, Seema, Sangeeta, Mrs. Trivedi, Pipee, Sita all met the same things from their up bringers.

In Third World context, a daughter is brought up with large supplements of fear that are the facts that she should be chaste, pure, and virtuous in order to be an ideal daughter, ideal wife and ideal mother. Such expectations and family teachings grow fear in their mind that impedes them. On the contrary, the Western girls are not fed up with such teachings like Indian girls. Karthika V.K. 
comments: "This notion of chastity is considered as a part of the pristine Indian culture which is different from the western culture which does not create a lot of differences between men and women." (Karthika, 2015) Women in Third World countries, have to pass chaste ordeals. Glorification of chastity or honour for virginity is echoed by the words of Third World mothers or grandmothers. A Third World wife has to prove her virginity in her bridal house as Astha proves it to Hemant. Otherwise, this girl is considered as impure and rejected.

In Third world society, conventional systems and customs are deep-seated and in the traditional system "Indianness" is structured around gender discrimination giving narrow space to female for freedom. Right from the marriage, the bride's integration into the family begins. She is directed and instructed into the lifestyle and habit of her husband's family. As Astha in Hemant's family, has submerged into the roles: wife, daughter-in-law, sister-in-law and mother. But despite her all efforts to dedicate herself genuinely to the well being of the family she is considered as an outsider. Astha wants a room that should be used for the sake of art and painting. She wants to possess some space of her own like Virginia Woolf's A Room of One's Own (1929). But this room was given to Sangeeta as she has to live with them. Again, Astha wants to buy a car with her inherited money from her parents. But now Hemant is the owner of this money. Once again she is rejected. It is the tradition in Third World Indian society that a daughter-in-law has to sacrifice for the happiness of others. But when the same bride turns into a mother-in-law, she holds an authoritative voice, particularly over the daughters-in-law; as Astha's mother-in-law's influence over Astha. In the same way, Astha will practice this tradition on Himanushu's wife. The Third World women become not only advocates but even the custodians of the same culture that impedes their liberal thoughts.

Women in India are victims of child marriage which is not only a problem but also a creator of so many problems. Child marriage is a violation of female rights which has a negative impact on physical growth, health, mental and emotional development, and education opportunities that consequently creates poverty and illiteracy. In Third World societies, child marriage or forced marriage is the main problem that subjugates women with a frequent number of pregnancies, premature maternal death, child death, complications in child birth etc. For the evil of child marriage, child brides often become child widows and lose honour and right to marry again. In this story, Mrs. Trivedi became a widow in her childhood and she had no right to remarry and was parted from her husband's family members; Sita and Astha's mother-in-law were child brides; and Seema and Sangeeta are the teenage brides.

Women in India have no security, no guarantee of a roof over their heads. The Indian girls never go against their families or go to court over being denied their rights to property. Women should have something of their name for security. In this story, Astha suffers a lot as all her property is registered in the name of Hemant. She cannot go against her mother or husband. Both persons deprived her 
bitterly. She could have bought a car or could have an art gallery by spending some portion of that money but all her money is transferred to Hemant. Her mother, in this case, chooses Hemant better than Astha because he is a man. It is the custom in Third World Indian society that money and property will be controlled by males which create a lot of problems in female empowerment and female liberty.

In India, women still lag behind regarding their divorce rights. They are fed up with the ideal of Indian womanhood. Even they cannot pronounce their rights for divorce rather they suffer from the sick of sacrifice. In contrast, Western countries, the divorce rate is three out of four. To quote Kapur: "There they go on divorcing-marrying till the age of $60-70$. They do not understand the concept of family. They only think of themselves." (Kapur: 168) But for Indian women, divorce is a shame and dishonour for their family. That is why thousands of women suffer in Third World societies for the outdated family name. As a result, women suffer like Sangeeta or Astha. But in First World societies, such false family notions cannot trap women. There, divorce is not a shame rather a wise decision in order to avoid family violence.

In India, Secular ideas are not accepted like European countries. Women are not allowed here to enjoy their lesbian rights. But in Western countries, there are no objections for lesbianism. There are many female-headed families in Western societies where lesbian women live and even marry. No objection comes from state or society. Women in Third World societies, live under male-headed family where heterosexuality is acceptable not homosexuality. Women cannot open their heart about lesbian relationship here. In this story, the lesbian lovers; Astha and Pipeelika hide their affairs on account of social obstacles and charges.

\section{Research Findings}

Many researchers have so far been pursued on Kapur's A Married Woman (2002). They celebrated Kapur's female characters as liberated and resistant heroines with the bounties of glory. But the social problems that re-colonize them are not mentioned by them. However, this research finds out the social impediments such as child marriage, forced marriage, gender discrimination, domestic work, family violence, education inequality, discourage for degree, family tradition, patriarchal hegemony, sexual exploitation and so on that cause barricades for the Indian women to walk on the open road of liberty.

\section{Conclusion}

In A Married Woman (Kapur, 2002) through the characters of Astha, Sita, Sangeeta Seema, Mrs, Trivedi and Pipeelika, Kapur reveals the prerequisites of a Third World married women. An Indian wife from bedroom to kitchen has to perform all household duties like cooking, cleaning, washing, upbringing children and taking care of husband and in-laws as Astha performs. In Third World Indian patriarchy, marriage is more important than education. Sita and Mrs, 
Trivedi are the victims of early marriage. Indian wives never dare to think of divorce and therefore, they often are victims of domestic violence or humiliation as Sangeeta faces in-law's house and Astha is often answerable for her any sort of negligence of household responsibilities to her husband and mother-in-law. Motherhood and family reputation are also important obstacles for Third world women for which they cannot divorce their husband. From the very beginning of their life, they are taught to be the bearer and upholder of family honour as Astha experiences. After their husband's death, Indian widows are considered as outsiders, untouchables and sinners as Sita and Pipeelika suffer from such public isolation. In fine, these are the social and familial impediments for Third World women that create barricades in female education, empowerment, employment, identity and independence.

\section{Conflicts of Interest}

The authors declare no conflicts of interest regarding the publication of this paper.

\section{References}

Basu, P. (2007). Radha Will Not Cook Today and Other Stories (N. Zaman, Ed.) Dhaka: Writers ink.

Beauvoir, S. D. (1949). The Second Sex (H. M. Parshley, Trans.) New York: Knopf.

Desai, A. (2001). Fire on the Mountain. Vintage.

Kapur, M. (2002). A Married Woman. New Delhi: IndiaInk.

Karthika, K. V. (2015). Rereading the Myths of Female Subjectivity: A Comparative Critiquing. Research Journal of English Language and Literature, 3, No. 3.

Saldanha, V. (2016). Global Sisters Report.

https://www.globalsistersreport.org/

https://www.globalsistersreport.org/column/equality/power-religion-over-women-indi a-43236

Woolf, V. (1929). A Room of One's Own. England: Hogarth Press. 